\title{
Chelated Minerals and Limestone Particle Sizes on \\ Performance and Bone Quality of Brown-Egg Layers
}

Special Issue Nutrition / 035-042

\section{-Author(s)}

\section{Cordeiro $\mathrm{CN}^{\prime}$}

Bastos-Leite SC"

Vasconcelos FCIII

Goulart CC"

Sousa AM"III

Costa $\mathrm{AC}^{\mathrm{IV}}$

Zootecnista formada pela Universidade Estadual Vale do Acaraú - UVA.

" Docente do Curso de Zootecnia da Universidade Estadual Vale do Acaraú - UVA

III Mestrando do Programa de Pós-Graduação em Zootecnia pela Universidade Estadual Vale do Acaraú - UVA.

Iv Graduando em Zootecnia na Universidade Estadual Vale do Acaraú - UVA.

\section{Mail Address}

Corresponding author e-mail address Carla Nágila Cordeiro

Av João Jaime Ferreira Gomes Filho, 213 Centro, 62580-000, Acaraú-CE, Brazil. 62580-000

Tel: $\quad$ (55 88) 997128524

Email: carlinha_nagila@hotmail.com

\section{neywords}

Laying, Organic, Sources of calcium, Tibia.

\section{ABSTRACT}

This study aimed to evaluate productive performance, egg quality, and bone quality of commercial brown-egg layers fed diets containing organic and inorganic minerals and three limestone particle sizes. A total of 288 birds at 64 weeks of age were distributed in a completely randomized design in a $2 \times 3$ factorial arrangement (two mineral sources and three limestone particle sizes) and eight replicates. The experiment lasted 112 days, divided into four periods. The following treatments were tested: $\mathrm{T} 1=$ inorganic minerals $+100 \%$ fine limestone; $\mathrm{T} 2=$ inorganic minerals $+50 \%$ fine limestone $+50 \%$ coarse limestone; $\mathrm{T} 3=$ inorganic minerals $+100 \%$ coarse limestone; $\mathrm{T} 4=$ inorganic ${ }_{+}$organic minerals $+100 \%$ fine limestone; $\mathrm{T} 5=$ inorganic + organic minerals $+50 \%$ fine limestone $+50 \%$ coarse limestone; and $\mathrm{T} 6=$ inorganic organic minerals $+100 \%$ coarse limestone. There was no significant interaction effect between the studied factors on any of the variables. No significant effect of the types of mineral mixes or limestone particle sizes were observed on the performance, egg quality, or bone quality variables evaluated. In conclusion, organic or inorganic minerals associated with limestone in fine, medium, or coarse particle sizes can be used in diets for brown-egg layers without affecting their productive performance, egg quality, or bone quality.

\section{INTRODUCTION}

In the last few years, the poultry industry has stood out for the level of technologies employed in the production of quality foods. Recent advances in animal nutrition are responsible for the considerable growth in this segment. In high-productivity systems like this one, any flaws in the formulation of poultry diets may lead to low efficiency, with economic losses.

Mineral supplements are usually added to balanced diets, since the ingredients utilized in larger proportions (corn and soybean) do not have sufficient amounts of these elements to meet the nutritional requirements of animals. Microminerals participate in several biochemical processes essential to animal growth and development, which makes their supplementation of great importance in the diet (Araujo et al., 2008), either in organic or inorganic form. Organic minerals feature a greater bioavailability in relation to usual sources (Maciel et al., 2010), and are thus readily absorbed and retained by birds, benefiting their productive performance, immune system and lifespan; besides reducing the excretion of trace minerals, which are potential pollutants (Brito et al., 2006).

In addition to demonstrating greater stability, organic minerals benefit from a biochemical protection against the different reactions that can take place in the diet itself, which would cause an expressive 
Cordeiro CN, Bastos-Leite SC, Vasconcelos FC, Goulart CC, Sousa AM, Costa AC decrease in nutrient absorption rates (Close, 1998). According to Pessoa et al. (2012), organic minerals present specific actions at cellular level and a greater bioavailability in relation to inorganic minerals. Thus, the use of these minerals in the composition of poultry diets may result in better performance for these animals.

The eggshell provides protection against microbial invasion and controls the water and gas exchange through the pores present in it's structure (RodriguezNavarro et al., 2002). Thus, shells with lower quality than desired may lead to contamination of the important content (yolk and albumen), compromising the dietary health of consumers.

In this way, there is a great concern with the integrity of eggshells and with their loss of quality throughout the productive life of layers. This decline in quality is due to factors like lower calcium retention (Pappas et al., 2006) and increased egg weight without a proportional increase in shell weight (Miles, 2008), since the daily deposition of calcium in the eggshell corresponds to $10 \%$ of the total stored in the bird's body (Ebling et al., 2012).

The shell formation process normally occurs during the night period, when birds do not have a labile calcium source in the digestive tract (Bueno, 2013), requiring it's partial removal from the bones. Therefore, it is argued that the limestone in larger particles remains retained in the gizzard until the release of calcium for the formation of the eggshell (Murata et al., 2009), thereby allowing it's slow release, making it available for the formation of the shell during the time birds are not feeding.

Calcium has a prominent position in layer diets, not only for being the main component of the eggshell, but also because of its considerable value in the bone composition of these birds. Recent research on the bone mineral density of poultry is of great relevance for the laying-poultry segment, aiming at their productive longevity. The bone mineral density can be evaluated by many techniques, e.g., the bone mineral composition, bone resistance, and the Seedor index (Almeida Paz et al.,2009).

In this regard, some alternatives have been proposed to improve eggshell quality, such as the use of organic minerals and the use of limestone with different particle sizes in diets. The present study was thus developed to evaluate the effect of organic minerals and three limestone particle sizes on the productive performance, egg quality, and bone quality of commercial brown-egg layers.

\section{MATERIAL AND METHODS}

The experiment was conducted in the Poultry Unit of the Experimental Farm at Universidade Estadual Vale do Acaraú - UVA, located in Sobral - CE, Brazil, consisting of four 28-day cycles. A total of $288 \mathrm{Hy}-$ Line Brown layers, at 64 weeks of age, with an average body weight of $1.88 \pm 0.036 \mathrm{~kg}$, were used in the trial.

The experimental design was completely randomized, in a $2 \times 3$ factorial arrangement (two types of mineral supplement and three limestone particle sizes), totaling six treatments, with eight replicates and six birds per experimental unit. Experimental diets were iso-nutrient and iso-caloric (Table 1), formulated according to the nutritional requirements suggested by the manual of the line (Hy-Line do Brasil, 2013). The following treatments were tested: $\mathrm{T} 1=$ inorganic minerals $+100 \%$ fine limestone; $\mathrm{T} 2=$ inorganic minerals $+50 \%$ fine limestone $+50 \%$ coarse limestone; $\mathrm{T3}=$ inorganic minerals $+100 \%$ coarse limestone; T4 = inorganic + organic minerals + 100\% fine limestone; T5 $=$ inorganic + organic minerals $+50 \%$ fine limestone $+50 \%$ coarse limestone; and T6 = inorganic + organic minerals $+100 \%$ coarse limestone. As for the particle size, according to the geometric diameter (Dg) of limestone particles, samples were classified as fine (Dg $0.35 \mathrm{~mm}$ ), medium (Dg $0.827 \mathrm{~mm}$ ), and coarse (Dg $1.762 \mathrm{~mm}$ ) (Zanotto \& Bellaver, 1996).

Birds were fed daily and had production recorded to generate performance data, based on which the following variables were evaluated: feed intake ( $\mathrm{g} / \mathrm{bird} /$ day), egg production (egg/bird/day), egg weight (g), egg mass (g/bird/day), conversion per egg mass (kg/ $\mathrm{kg})$, and conversion per dozen eggs ( $\mathrm{kg} / \mathrm{dz}$ ).

At the end of each 28-day period, four eggs were collected per replicate for the analysis of egg quality, in which the percentages of albumen, shell, yolk, and cracked eggs; shell thickness ( $\mathrm{mm})$; and specific gravity $(\mathrm{g} / \mathrm{cm} 3)$ were determined, following the methodology described by Bezerra et al. (2015).

At the end of the experiment, one bird was taken at random per replicate and sacrificed by cervical dislocation for removal of drumsticks and thighs, which were frozen at $-20^{\circ} \mathrm{C}$ until deboning.

For the deboning procedure, the pieces were removed from the freezer and left to thaw on countertops until they reached room temperature. Afterwards, drumsticks and thighs were immersed in boiling water for $10 \mathrm{~min}$ and then deboned, following the methodology described by Bruno et al (2007). 
For the assessment of bone quality, only the tibiae were used. The bone length was measured using a digital caliper, and the weight was obtained on an electronic scale with $0.01 \mathrm{~g}$ precision. Bone density was evaluated by the Seedor index, obtained by dividing the weight $(\mathrm{mg})$ by the length $(\mathrm{mm})$ of the evaluated bone (Seedor et al., 1991).

Bone resistance and deformity were analyzed at the Laboratory of Soil Mechanics at the Department of Transport Engineering of Universidade Federal do Ceará, using a mechanical press. Left tibiae were placed in the horizontal position, and a compression force was applied to the center of each bone. The maximum force applied to the bone until it's rupture was on it's breaking strength $\left(\mathrm{kgf} / \mathrm{cm}^{2}\right)$, measured using an electronic extensometer. Deformity $(\mathrm{mm})$ was measured using an analogical extensometer until the moment of bone rupture.

The ash content was determined at the Laboratory of Animal Nutrition (LANUT) of UVA. After deboning, right tibiae were weighed and dried in a forced-air oven at $105^{\circ} \mathrm{C}$ for $72 \mathrm{~h}$. Subsequently, they were weighed and ground with a mortar and pestle. Ground samples were then identified for determination of mineral matter (MM) according to the methodology described by Silva \& Queiroz (2002).

The average of the variables of the four evaluated periods were considered. The results obtained, with the use of the two mineral sources tested, were subjected to analysis of variance $(5 \%)$ by the $\mathrm{F}$ test; whereas the mean values for the different particle sizes were compared by Tukey's test at 5\% (SAS, 2000) and subsequently analyzed by a factorial model including the effects of treatments, mineral sources, limestone particle sizes, and the interaction between the factors.

\section{RESULTS AND DISCUSSION}

No significant interaction was observed between the studied factors for any of the performance variables assessed. Likewise, there were no significant effects of the types of mineral supplement and the three limestone particle sizes on the following variables: feed intake, egg production, egg weight, egg mass,

Table 1 - Centesimal and calculated nutritional composition of experimental diets.

\begin{tabular}{|c|c|c|c|c|c|c|}
\hline \multirow{2}{*}{ Ingredient } & \multicolumn{6}{|c|}{ Quantity (\%) } \\
\hline & T11 & $\mathrm{T} 2^{1}$ & T31 & T41 & T51 & T61 \\
\hline Ground corn & 57.472 & 57.472 & 57.472 & 57.402 & 57.402 & 57.402 \\
\hline Soybean meal (45\%) & 27.398 & 27.398 & 27.398 & 27.398 & 27.398 & 27.398 \\
\hline Soybean oil & 1.750 & 1.750 & 1.750 & 1.750 & 1.750 & 1.750 \\
\hline Dicalcium phosphate & 1.416 & 1.416 & 1.416 & 1.416 & 1.416 & 1.416 \\
\hline Common salt & 0.363 & 0.363 & 0.363 & 0.363 & 0.363 & 0.363 \\
\hline DL-methionine & 0.149 & 0.149 & 0.149 & 0.149 & 0.149 & 0.149 \\
\hline Fine limestone $(\mathrm{Dg}=0.35 \mathrm{~mm})$ & 11.052 & 5.526 & & 11.052 & 5.526 & \\
\hline Coarse limestone $(\mathrm{Dg}=1.762 \mathrm{~mm})$ & & 5.526 & 11.052 & & 5.526 & 11.052 \\
\hline Layer Premix 0.4\% 500TEC* & 0.400 & 0.400 & 0.400 & 0.400 & 0.400 & 0.400 \\
\hline Layer Premix 0.07\% QLT** & & & & 0.070 & 0.070 & 0.070 \\
\hline \multicolumn{7}{|l|}{ Calculated Nutritional Composition } \\
\hline Metabolizable energy (Cal/kg) & 2750 & 2750 & 2750 & 2750 & 2750 & 2750 \\
\hline Crude protein $(\mathrm{g} / \mathrm{kg}$ ) & 17.50 & 17.50 & 17.50 & 17.50 & 17.50 & 17.50 \\
\hline Calcium $(\mathrm{g} / \mathrm{kg})$ & 4.70 & 4.70 & 4.70 & 4.70 & 4.70 & 4.70 \\
\hline Available phosphorus (g/kg) & 0.36 & 0.36 & 0.36 & 0.36 & 0.36 & 0.36 \\
\hline Sodium $(\mathrm{g} / \mathrm{kg})$ & 0.18 & 0.18 & 0.18 & 0.18 & 0.18 & 0.18 \\
\hline Chlorine (\%) & 0.25 & 0.25 & 0.25 & 0.25 & 0.25 & 0.25 \\
\hline Dig. methionine + cystine $(\mathrm{g} / \mathrm{kg})$ & 0.690 & 0.690 & 0.690 & 0.690 & 0.690 & 0.690 \\
\hline Dig. methionine $(\mathrm{g} / \mathrm{kg})$ & 0.449 & 0.449 & 0.449 & 0.449 & 0.449 & 0.449 \\
\hline Lysine $(\mathrm{g} / \mathrm{kg})$ & 0.810 & 0.810 & 0.810 & 0.810 & 0.810 & 0.810 \\
\hline
\end{tabular}

${ }^{1} \mathrm{~T} 1$ = inorganic minerals $+100 \%$ fine limestone; $\mathrm{T} 2=$ inorganic minerals $+50 \%$ fine limestone $+50 \%$ coarse limestone; $\mathrm{T} 3=$ inorganic minerals $+100 \%$ coarse limestone; $\mathrm{T} 4=$ inorganic + organic minerals $+100 \%$ fine limestone; $\mathrm{T} 5=$ inorganic + organic minerals $+50 \%$ fine limestone $+50 \%$ coarse limestone; and T6 = inorganic + organic minerals + $100 \%$ coarse limestone.

*PREMIX - 0.4\% 500 (inorganic) - guaranteed levels (composition per kg of product): iron (min) 10.00 mg/kg; copper (min):2,500.00 mg/kg; zinc (min): $20.00 \mathrm{~g} / \mathrm{kg}$; manganese (min) $20.00 \mathrm{mg} / \mathrm{kg}$; iodine (min) $208.00 \mathrm{mg} / \mathrm{kg}$; selenium (min): $75.15 \mathrm{mg} / \mathrm{kg}$; vitamin A (min): 2,000,000.00 IU/kg; vitamin D3 (min): 625,000.00 IU/kg; vitamin E (min): 3,000.00 IU/Kg; vitamin K3 (min): $395.92 \mathrm{IU} / \mathrm{kg}$; folic acid (min): $74.25 \mathrm{mg} / \mathrm{kg}$; choline (min): $100.00 \mathrm{~g} / \mathrm{kg}$; niacin (min): 5,025.74 mg/kg; pantothenic acid (min) 1,805.16 mg/kg; vitamin B1 (min): $250.09 \mathrm{mg} / \mathrm{kg}$; vitamin B2 (min): 1,000.00 mg/kg; vitamin B6 (min): 250.1 mg; vitamin B12 (min): 2,400.00 mcg/kg; methionine (min): $125,00 \mathrm{~g} / \mathrm{kg} ;$ colistin (min): 1,750.00 mg/kg. **PREMIX - 0.07\% QLT (chelated) - guaranteed levels (composition per kg of product):copper (min) 7,143.00 mg/kg; zinc (min) $57.00 \mathrm{~g} / \mathrm{kg} ;$ manganese (min) $57.00 \mathrm{~g} / \mathrm{kg} ;$ vitamin A (min) 1,428,600.00 IU/kg; vitamin D3 (min) 1,428,550.00 IU/kg; vitamin E (min) 5,714,000.00 IU/kg. 
conversion per egg mass, or conversion per dozen eggs (Table 2). In this way both mineral supplements employed here, show to be adequate to maximize these productive parameters with no additional effects of the use of chelated minerals in the diets.

The results of the present study corroborate those reported by Fernandes et al. (2008), Maciel et al. (2010), Passos et al. (2011), and Dikmen et al. (2015), who, working with chelated minerals in the feeding of layers, similarly did not find positive effects of their addition on poultry performance. Studies conducted by Ito et al. (2006) using two limestone particle sizes, reported no differences in feed intake, feed conversion, egg production, egg weight, or mass of eggs produced.

By contrast, Figueiredo Junior et al. (2013) worked with supplementation of 33,66 , and $100 \%$ of substitution of inorganic minerals, by organic minerals in diets for brown-egg layers at 68 weeks of age and reported that better results for production, egg weight, and conversion per mass and per dozen were found when organic minerals replaced the inorganic by $66 \%$.

Regarding the limestone particle sizes, similar results were obtained by Murata et al. (2009), who used 0 , $25,50,75$, and $100 \%$ coarse limestone to substitute the fine version, in the feeding of commercial layers. The variables: egg production, feed conversion, and egg weight were not influenced by the particle sizes tested. Similarly, working with limestone in fine, coarse, and gravel sizes in diets for white-egg layers, Jardim Filho et al. (2005) reported that they did not influence performance variables.
Conflicting results were reported by Garcia et al. (2012), who worked with five levels of inclusion of coarse limestone, replacing it's fine version $(0,25$, 50,75 , and $100 \%$ ) in diets for brown-egg layers at 53 weeks of age; and observed that intake, egg production, and egg mass decreased as the inclusion of coarse limestone in the diet was increased.

Better results were expected for intake in the treatments that involved the limestone in coarse particles, because older birds prefer larger particles, and, when they ingest them, they would do so also with the smaller particles of the diet, improving their intake as a whole, which was not observed. The limestone particle sizes were not sufficient to influence intake, probably due to the good intake capacity shown by the birds, demonstrating that after the initial adaptation, brown-egg layers normalize their intake throughout the production cycle.

No significant interaction was observed between the studied factors on any of the egg-quality variables evaluated. Likewise, there was no significant effect of the two mineral sources and limestone particle sizes on the variables percentage of albumen, yolk and shell; shell thickness, specific gravity or percentage of cracked eggs (Table 3).

Although the organic mineral sources have a greater availability (Pessoa et al., 2012), promoting better performance when ingested; in the present study, no improvement was recorded with regards to the internal or external quality of the eggs. In the literature, results for the use of chelated minerals are highly controversial as to their influence on the egg's

Table 2 - Mean values referring to performance parameters of brown-egg layers fed diets containing inorganic or organic minerals and three limestone particle sizes.

\begin{tabular}{|c|c|c|c|c|c|c|}
\hline \multirow[b]{2}{*}{ Factors } & \multicolumn{6}{|c|}{ Variables } \\
\hline & FI (g/hen/day) & $\mathrm{EP}(\%)$ & Egg weight (g) & EM (g/hen/day) & FC/EM (kg/kg) & $\mathrm{FC} / \mathrm{DZ}(\mathrm{kg} / \mathrm{kg})$ \\
\hline \multicolumn{7}{|l|}{ Minerals } \\
\hline Inorgânic & 111,11 & 78.33 & 64.86 & 50.80 & 2.158 & 1.673 \\
\hline Inorg+Organic & 109,81 & 78.09 & 64.40 & 50.40 & 2.163 & 1.699 \\
\hline \multicolumn{7}{|l|}{ Limestone } \\
\hline Fine & 108,44 & 77.62 & 64.60 & 50.20 & 2.155 & 1.691 \\
\hline Fine+Coarse & 111,19 & 77.44 & 64.16 & 49.79 & 2.193 & 1.705 \\
\hline Coarse & 111,76 & 79.58 & 65.15 & 51.82 & 2.132 & 1.661 \\
\hline $\mathrm{CV}^{2}(\%)$ & 5,72 & 4.44 & 2.36 & 4.81 & 5.33 & 5.23 \\
\hline Mean & 110,46 & 78.21 & 64.64 & 50.60 & 2.160 & 1.686 \\
\hline ANOVA $^{2}$ & \multicolumn{6}{|c|}{ p-value } \\
\hline Minerals (M) & 0,4817 & 0,8126 & 0,3011 & 0,5725 & 0,8964 & 0,3314 \\
\hline Limestone (L) & 0.2934 & 0,1690 & 0,1995 & 0,0553 & 0,4088 & 0,4102 \\
\hline$M \times L$ & 0.2597 & 0,7440 & 0,6829 & 0,6060 & 0,7745 & 0,8090 \\
\hline
\end{tabular}

${ }^{1} \mathrm{CV}$ - coefficient of variation; FI - feed intake; EP - egg production; EM - egg mass; FC/EM-feed conversion per egg mass; FC/DZ- feed conversion per dozen eggs.

A, BMeans followed by different uppercase letters in the row differ statistically by Tukey's test at $5 \%$.

a, bMeans followed by different lowercase letters in the row differ statistically by Tukey's test at $5 \%$. 
Table 3 - Mean values referring to quality of eggs from commercial brown-egg layers fed diets with inorganic or organic minerals and three limestone particle sizes.

\begin{tabular}{|c|c|c|c|c|c|c|}
\hline \multirow[b]{2}{*}{ Factores } & \multicolumn{6}{|c|}{ Variables } \\
\hline & Albumen (\%) & Yolk (\%) & Shell (\%) & $\mathrm{ST}^{2}(\mathrm{~mm})$ & $\mathrm{SG}^{3}\left(\mathrm{~g} / \mathrm{cm}^{3}\right)$ & Cracked eggs (\%) \\
\hline \multicolumn{7}{|l|}{ Mineral } \\
\hline Inorganic & 62.98 & 25.38 & 9.82 & 0.384 & 1.096 & 1.23 \\
\hline Organic & 62.87 & 25.08 & 9.87 & 0.384 & 1.096 & 1.22 \\
\hline \multicolumn{7}{|l|}{ Limestone } \\
\hline Fine & 63.07 & 25.26 & 9.90 & 0.386 & 1.096 & 1.24 \\
\hline Fine+Coarse & 62.58 & 25.46 & 9.86 & 0.384 & 1.097 & 1.19 \\
\hline Coarse & 63.13 & 24.97 & 9.77 & 0.381 & 1.095 & 1.26 \\
\hline $\mathrm{CV}^{1}(\%)$ & 2.34 & 3.92 & 3.41 & 3.32 & 0.183 & 19.26 \\
\hline Mean & 62.92 & 25.23 & 9.84 & 0.384 & 1.096 & 1.23 \\
\hline ANOVA $^{2}$ & \multicolumn{6}{|c|}{$\mathrm{p}$-value } \\
\hline Minerals (M) & 0,7651 & 0,2974 & 0,6473 & 0,9961 & 0,5823 & 0,9724 \\
\hline Limestone (L) & 0,5021 & 0.3856 & 0,5378 & 0,6223 & 0,5328 & 0,6924 \\
\hline$M \times L$ & 0,4099 & 0.6584 & 0,7649 & 0,8352 & 0,6028 & 0,5706 \\
\hline
\end{tabular}

${ }^{1} \mathrm{CV}$ - coefficient of variation; ${ }^{2}$ ST - shell thickness; ${ }^{3}$ SG-specific gravity.

A, B Means followed by different uppercase letters in the row differ statistically by Tukey's test at $5 \%$.

$\mathrm{a}, \mathrm{b}$ Means followed by different lowercase letters in the row differ statistically by Tukey's test at $5 \%$.

quality. This fact can be explained in part, by the large variety of chelated molecules existing and their differences in bioavailability and stability as well as their metabolism in the animal's body (Maciel et al., 2010).

Lack of effects of chelated minerals on the egg's quality parameters was also reported by Swiatkiewicz \& Koreleski (2008), Saldanha et al. (2009), and Geraldo et al. (2012). On the contrary, Maciel et al. (2010), working with layers at the end of their laying period, using diets containing $50 \%$ organic mineral supplementation, associated $(\mathrm{Zn}+\mathrm{Cu}+\mathrm{Mn})$ or isolated, concluded that associated supplementation provided better results than zinc, copper, or manganese separately, as it resulted in lower loss of eggs, greater specific gravity and heavier eggs.

Working with brown-egg layers fed diets with and without organic minerals, Figueiredo Júnior et al. (2013) reported that the percentage of albumen, specific gravity and shell thickness had better results when inorganic minerals were replaced with organic minerals by $66 \%$.

The quality variables were not influenced by any of the limestone particle sizes tested. Better results were expected for percentage of shell, shell thickness and specific gravity in the treatments with coarse limestone, since this particle size was assumed to provide more calcium for the formation of the shell, due to it's longer permanence in the tract, thereby improving its quality, which was not observed in this experiment. Probably, for presenting a greater feed intake capacity (Jardim Filho et al., 2005), the brown-egg layers consequently consumed a sufficient amount of nutrients for the formation of the eggshell, irrespective of the limestone particle size utilized in the diet.

Additionally, literature reports describe that in situations in which diets have appropriate calcium levels, coarse limestone is not necessarily essential to the supply of this mineral (Witt et al., 2009).

Working with limestone in five particle sizes in the feeding of white-egg layers, Murata et al. (2009) concluded that the use of granulated limestone did not benefit the egg quality, which this study corroborates. Similar results were reported by Garcia et al. (2012), who increasingly replaced finely ground limestone $(0.145 \mathrm{~mm})$ by its coarse form $(3.18 \mathrm{~mm})$ in the diet of layers at the end of production and concluded that particle size did not affect the internal or external egg quality.

The results of the present study differ from those presented by Lemos et al. (2011), who evaluated the external quality of eggs from brown-egg layers and observed that the coarse limestone particle size (2 $\mathrm{mm}$ ) improved the percentage of the eggshell, thereby improving the egg quality. Jardim Filho et al. (2005) also observed improved eggshell quality after feeding the birds with coarse limestone $(2.00 \mathrm{~mm})$.

No significant interaction was observed between the studied factors for any of the bone-quality variables. Similarly, there was no significant effect of either mineral source or limestone particle size on the following variables: tibia weight, length, Seedor index, resistance, deformity and mineral matter (Table 4). 
Table 4 - Mean values for weight, length, Seedor index (SI), resistance, deformity and mineral matter of tibiae from brownegg layers fed diets containing inorganic or organic minerals and three limestone particle sizes.

\begin{tabular}{|c|c|c|c|c|c|c|}
\hline \multirow[b]{2}{*}{ Factores } & \multicolumn{6}{|c|}{ Variables } \\
\hline & Weight (g) & Length $(\mathrm{mm})$ & $\mathrm{SI}(\mathrm{mg} / \mathrm{mm})$ & Resistance $\left(\mathrm{kgf} / \mathrm{cm}^{2}\right)$ & $\begin{array}{l}\text { Deformity } \\
(\mathrm{mm})\end{array}$ & $\begin{array}{c}\text { Mineral matter } \\
(\mathrm{g} / \mathrm{kg})\end{array}$ \\
\hline \multicolumn{7}{|l|}{ Mineral } \\
\hline Inorganic & 10.59 & 118.74 & 89.09 & 5.04 & 2.29 & 43.56 \\
\hline Organic & 10.21 & 120.80 & 84.32 & 5.07 & 2.17 & 45.27 \\
\hline \multicolumn{7}{|l|}{ Limestone } \\
\hline Fine & 10.63 & 120.82 & 87.98 & 5.76 & 2.41 & 44.34 \\
\hline Fine+Coarse & 10.19 & 119.03 & 85.38 & 4.26 & 2.15 & 43.79 \\
\hline Coarse & 10.37 & 119.46 & 86.75 & 4.97 & 2.11 & 45.12 \\
\hline CV (\%) & 11.64 & 3.17 & 9.59 & 25.69 & 24.42 & 9.72 \\
\hline Mean & 10.40 & 119.77 & 86.70 & 5.06 & 2.23 & 44.41 \\
\hline ANOVA $^{2}$ & \multicolumn{6}{|c|}{$p$-value } \\
\hline Minerals (M) & 0.3986 & 0.1506 & 0.1295 & 0.9555 & 0.5813 & 0.2906 \\
\hline Limestone (L) & 0.7195 & 0.5556 & 0.7845 & 0.0733 & 0.4331 & 0.7905 \\
\hline $\mathrm{MxL}$ & 0.7575 & 0.4563 & 0.6635 & 0.5046 & 0.5657 & 0.6905 \\
\hline
\end{tabular}

'CV- coefficient of variation.

A, B Means followed by different uppercase letters in the row differ statistically by Tukey's test at $5 \%$.

${ }^{a, b}$ Means followed by different lowercase letters in the row differ statistically by Tukey's test at $5 \%$.

The bone is a type of connective tissue formed by an organic matrix, in which microminerals (copper, manganese, and zinc), as enzymatic cofactors, have a fundamental role in its synthesis and a mineral portion, constituted of calcium phosphate (Nunes et al. 2013). Therefore, a balanced diet provides the nutrients necessary for formation of bones with quality, resulting in more resistant bones, and decreasing animal loss caused by their fragility, which comes with age. Hence, the results found in the present experiment, demonstrated that the two mineral supplements provided the nutrients necessary for the good bone quality obtained. It can thus be inferred that, in this case, the organic minerals utilized do not show advantages in relation to the inorganic source as to bone quality.

Similar results to those found in this trial for bone resistance were reported by Nunes et al. (2013), who worked with supplementation of increasing levels of $\mathrm{Cu}, \mathrm{Mn}, \mathrm{Zn}$ and Fe proteinates in diets for brown-egg layers in the period from 30 to 70 weeks of age. Conflicting results were published by Carvalho (2013), who described an improvement in bone resistance of layers fed diets containing organic mineral supplementation.

Brito et al. (2006) worked with chelated minerals in diets for replacement pullets of 7 to 12 weeks of age and reported that treatments did not influence length, weight or ash content of the tibia of these birds. These results are similar to those found in the present study. Likewise, Swiatkiewicz \& Koreleski (2008) also reported no effect of organic mineral supplementation on the length, deformity and ash content of the tibia from brown-egg layers.
Working with increasing levels of coarse limestone for white-egg layers, Oliveira et al. (2013) observed that the limestone particle size did not influence the Seedor index or the mineral matter; the present study corroborates these findings.

Contrasting results were reported by Cufadar et al. (2011), who utilized three levels of calcium and three limestone particle sizes $(2 \mathrm{~mm}, 3$ to $5 \mathrm{~mm}$, and over $5 \mathrm{~mm}$ ) in the diet of brown-egg layers. These authors suggested the use of limestone of medium particle size as the most suitable to maintain poultry bone quality.

\section{CONCLUSION}

Diets containing inorganic minerals or these associated with organic minerals, along with different limestone particle sizes - fine, medium, or coarse -, can be used in the feeding of commercial layers without affecting their production performance, egg quality, or bone quality.

\section{ACKNOWLEDGMENTS}

To God; to Tecnavic for the donation of materials; to $\mathrm{Hy}$-line do Brasil for the donation of chicks; and to Funcap for the 'scientific initiation' fellowship grant.

\section{REFERENCES}

Almeida Paz ICL, Mendes AA, Balog A, Komiyama CM, Takahashi SE, Almeida ICL, et al. Efeito do cálcio na qualidade óssea e de ovos de poedeiras. Archivos de Zootecnia 2009;58(222):173-183. 
Araujo JA, Silva JHV Amâncio ALL, Lima CB, Oliveira ERA. Fontes de minerais para poedeiras. Acta Veterinária Brasilica 2008;2(3):53-60.

Brito JAG, Bertechini AG, Fassani EJ, Rodrigues PB, Freitas RTF. Uso de microminerais sob a forma de complexo orgânico em rações para frangas de reposição no período de 7 a 12 semanas de idade. Revista Brasileira de Zootecnia 2006;35(4):1342-1348.

Bezerra, RM, Costa, FGP, Givisiez, PEN, Goulart, CC, Santos, RA, Lima, MR. Glutamic acid supplementation on low protein diets for laying hens. Acta Scientiarum Animal Science 2015;37(2):129-134.

Bruno LGD, Luquetti BC, Furlan RL, Macari M. Influence of early qualitative feed restriction and environmental temperature on long bone development of broiler chickens. Journal of Thermal Biology 2007:32:349-354

Bueno IJM. Influência da granulometria do calcário em ovos de matrizes avícolas de segundo ciclo [thesis]. Curitiba (PR): Universidade Federal do Paraná; 2013.

Carvalho LSS. Microminerais orgânicos em substituição a fonte inorgânica de minerais para poedeiras:efeitos sobre a produtividade e excreção mineral - tradução. Revista Cientifíca Eletrônica de Medicina Veterinária 2013;11(20).

Close WH. The role of trace mineral proteinates in pig nutrition. Proceedings of the $14^{\text {th }}$ Alltech's Annual Symposium;1998; Nottingham: Nottingham University; 1998. p.469-376

Cufadar Y, Olgun O, Yildiz AÖ. The effect of dietary calcium concentration and particle size on performance, eggshell quality and bone mechanical properties and tibia mineral contents in moulted laying hens. British Poultry Science 2011;52(6):761-768

Dikmen BY, Sözcü ZCÜ A, Ipek A, Şahan Ü. Effects of supplementary mineral amino acid chelate ( $Z n A A-M n A A)$ on the laying performance, egg quality and some blood parameters of late laying period layer hens. Kafkas Univ Vet Fak Derg 2015;21(2):155-162.

Ebling PD, Zanella I, Karkow AK, Alves DA, Santos JPA, Pigozzo JC. Métodos de incorporação da enzima fitase em rações para poedeiras. Ciência Rural 2012;42(1):160-165

Fernandes JIM, Murakami AE, Sakamoto MI, Souza LMG, Malaguido A, Martins EM. Effects of Organic Mineral Dietary Supplementation on Production Performance and Egg Quality of White Layers. Brazilian Journal of Poultry Science 2008;10(1):59-65.

Figueiredo Júnior JP, Costa FGP, Givisiez PEN, Lima MR; Silva JHV, FigueiredoLima DF, et al. Substituição de minerais inorgânicos por orgânicos na alimentação de poedeiras semipesadas . Arquivo Brasileiro de Medicina Veterinária e Zootecnia 2013;65(2):513-518

Garcia ERM, Batista NR, Cruz FK, Barbosa Filho JA. Granulometria do calcário: desempenho e qualidade dos ovos de poedeiras em final de produção. Zootecnia Tropical 2012;30(4):311-316.

Geraldo A, Pinto DM, Brito JAG, Bernardes MH, Silva Junior AL, Machado LC. Diferentes programas de suplementação de microminerais para poedeiras semipesadas em primeiro ciclo de produção. Arquivos de Pesquisa Animal 2012;1(1):48-57.

Hy Line do Brasil. Manual da linhagem: poedeiras comerciais HyLine Brown; 2013 [cited 2015 Feb 26]. Available from: http://www.hylinedobrasil. com.br/hyline/download/guia_brown_E2.pdf.

Ito DT, Faria DE, Kuwano EA, Junqueira OM, Araujo LF. Efeitos do fracionamento do cálcio dietário e granulometria do calcário sobre o desempenho e qualidade dos ovos de poedeiras comerciais. Acta Scientiarum. Animal Sciences 2006:28(2):187-195.

Jardim Filho RM, Stringhini JH, Café MB, Leandro NSM, Cunha WCP, Nascimento Junior O. Influência das fontes e granulometria do calcário calcítico sobre o desempenho e a qualidade da casca dos ovos de poedeiras comerciais. Acta Scientiarum Animal Sciences 2005;27:3541.
Lemos MJ, Calixto LFL, Lima CAR, Agostinho TSP, Araújo MO, Couto IS. Influência da granulometria do calcário sobre a qualidade da casca de ovos produzidos por poedeiras semi pesadas criadas no piso. Boletim Indústria animal 2011;68(2):151-155.

Maciel MP, Saraiva EP, Aguiar EF, Ribeiro PAP, Passos DP, Silva JB. Effect of using organic microminerals on performance and external quality of eggs of commercial laying hens at the end of laying. Revista Brasileira de Zootecnia 2010;39:344-348.

Miles R. Fatores nutricionais relacionados à qualidade de casca dos ovos; 2000 [cited 2015 Apr 06]. Available from: http://www.caodobrasil. com.br/?pg=dicas_e_artigos\&codigo $=6$.

Murata LS, Ariki J, Santana AP. Níveis de cálcio e granulometria do calcário sobre o desempenho e a qualidade da casca de ovos de poedeiras comerciais. Revista Biotemas 2009;22(1):103-110.

Nunes JK, Santos VL, Rossi P, Anciuti MA, Rutz F, Maier JC, Silva JGC. Qualidade de ovos e resistência óssea de poedeiras alimentadas com minerais orgânicos. Arquivo Brasileiro Medicina Veterinária e Zootecnia 2013;65(2):610-618.

Oliveira NA, Freitas ER, Fikgueira TMB, Cruz CEB, Nascimento JAJ. Limestone particle size and artificial light for laying hens in the second laying cycle. Revista Brasileira de Zootecnia 2013;42(7):481-488.

Pappas AC, Acamovic T, Sparks NHC, Surai PF, McDevitt RM. Effects of supplementing broiler breeder diets with organoselenium compounds and polyusatured fatty acids on hatchability. Poultry Science 2006;85:1584-1593.

Passos DP, Maciel MP, Cardoso DM, Reis ST, Arouca CLC, Dias AN. Microminerais orgânicos e vitamina $C$ nas rações de poedeiras semipesadas em região de clima quente. Revista Portuguesa de Ciências Veterinária 2013;108(585-586):53-57.

Pessôa GBS, Tavernari FC, Vieira RA, Albino LfT. Novos conceitos em nutrição de aves. Revista Brasileira Saúde Produção Animal 2012;13(3):755-774

Rodriguez-Navarro A, Kalin O, Nys Y, Garcia-Ruiz JM. Influence of the microstructure on the shell strength of eggs laid by hens of different ages. British Poultry Science 2002;43:395-403.

Saldanha ESBP, Garcia EA, Pizzolante CC, Faittarone ABG, Sechinato A da, Molino $A B$, et al. Effect of organic mineral supplementation on the egg quality of semi-heavy layers in their second cycle of lay. Brazilian Journal of Poultry Science 2009;11(4):215-222.

SAS Institute. Sas users guide: statistics. version 8. Cary; 2000.

Seedor JG, Quarraccio HH, Thompson DD. The biophosphonate alendronate (MK-217) inhibits bone loss due to ovariectomy in rats. Boneand Mineral Resources 1991;6:339-346.

Silva DJ, Queiroz AC. Análises de alimentos: métodos químicos e biológicos. Viçosa: UFV; 2002.

Swiatkiewicz S, KoreleskiJ. The effect of zinc and manganese source in the diet for laying hens on eggshell and bones quality. Veterinarni Medicina 2008;53(10):555-563.

Zanotto DL, Bellaver,C. Método de determinação da granulometria de ingredientes para uso em rações de suínos e aves [comunicado técnico, 215]. Concórdia: Embrapa-CNPSA; 1996. Available from: http://www. cnpsa.embrapa.br/sgc/sgc_publicacoes/cot215.pdf

Witt FH, Kuleile NP, Van der Merwe HJ, Fair MD. Effect of limestone particle size on egg production and eggshell quality of hens during late production. South African Journal of Animal Science 2009;39(Suppl 1). 
